Pesq. Vet. Bras. 35(1):95-98, janeiro 2015

DOI: $10.1590 / \mathrm{S} 0100-736 \mathrm{X} 2015000100018$

\title{
Lactated Ringer's solution or $0.9 \%$ sodium chloride as fluid therapy in pigeons (Columba livia) submitted to humerus osteosynthesis ${ }^{1}$
}

\author{
Adriano B. Carregaro ${ }^{2 *}$, Martielo I. Gehrcke ${ }^{3}$, Jenifer S. Marques ${ }^{3}$, André N.E. Silva ${ }^{2}$ \\ and Kleber T. Gomes ${ }^{3}$
}

\begin{abstract}
Carregaro A.B., Gehrcke M.I., Marques J.S., Silva A.N.E. \& Gomes K.T. 2015. Lactated Ringer's solution or $0.9 \%$ sodium chloride as fluid therapy in pigeons ( $\mathrm{Co}$ lumba livia) submitted to humerus osteosynthesis. Pesquisa Veterinária Brasileira 35(1):95-98. Departamento de Medicina Veterinária, Universidade de São Paulo, Av. Duque de Caxias Norte 225, Pirassununga, SP 13635-900, Brazil. E-mail: carregaro@usp.br

The study aimed to compare the effects of intraosseous infusion of lactated Ringer's and $0.9 \%$ sodium chloride solutions on the electrolytes and acid-base balance in pigeons submitted to humerus osteosynthesis. Eighteen pigeons were undergoing to isoflurane anesthesia by an avalvular circuit system. They were randomly assigned into two groups ( $n=9)$ receiving lactated Ringer's solution (LR) or $0.9 \%$ sodium chloride (SC), in a continuous infusion rate of $20 \mathrm{~mL} / \mathrm{kg} / \mathrm{h}$, by using an intraosseous catheter into the tibiotarsus during 60-minute anesthetic procedure. Heart rate (HR), and respiratory rate (RR) were measured every $10 \mathrm{~min}$. Venous blood samples were collected at 0,30 and 60 minutes to analyze blood $\mathrm{pH}, \mathrm{PvCO}_{2}, \mathrm{HCO}_{3}{ }^{-}, \mathrm{Na}^{+}$and $\mathrm{K}^{+}$. Blood gases and electrolytes showed respiratory acidosis in both groups during induction, under physical restraint. This acidosis was evidenced by a decrease of $\mathrm{pH}$ since $0 \mathrm{~min}$, associated with a compensatory response, observed by increasing of $\mathrm{HCO}_{3}^{-}$concentration, at 30 and $60 \mathrm{~min}$. It was not observed any changes on $\mathrm{Na}^{+}$and $\mathrm{K}^{+}$serum concentrations. According to the results, there is no reason for choosing one of the two solutions, and it could be concluded that both fluid therapy solutions do not promote any impact on acid-base balance and electrolyte concentrations in pigeons submitted to humerus osteosynthesis.
\end{abstract}

INDEX TERMS: Pigeons, Columba livia, osteosynthesis, fluid therapy, intraosseous infusion, bicarbonate, acid-base imbalance.

RESUMO.- [Fluidoterapia com Ringer lactato ou cloreto de sódio $0,9 \%$ em pombos (Columbia livia) submetidos à osteossíntese de úmero.] 0 presente estudo avaliou os efeitos da infusão das soluções de Ringer lactato ou cloreto de sódio $0,9 \%$, no equilíbrio ácido-base e hidroeletrolítico de pombos submetidos à osteossíntese de úmero. Foram utilizados 18 animais, os quais foram submetidos à anestesia por isofluorano, e mantidos em circuito avalvular

\footnotetext{
${ }^{1}$ Received on December 5, 2014.

Accepted for publication on January 31, 2015.

${ }^{2}$ Departamento de Medicna Veterinária, Universidade de São Paulo (USP), Av. Duque de Caxias Norte 225, Pirassununga, SP 13635-900, Brazil. *Corresponding author: carregaro@usp.br

${ }^{3}$ Departamento de Clínica de Pequenos Animais, Universidade Federal de Santa Maria (UFSM), Av. Roraima 1000, Bairro Camobi, Santa Maria, RS 97105-900, Brazil.
}

durante o período anestésico (60 $\mathrm{min}$ ). Os animais foram distribuídos aleatoriamente em dois grupos $(\mathrm{n}=9)$ recebendo Ringer lactato (LR) ou cloreto de sódio 0,9\% (SC), administradas na taxa de $20 \mathrm{~mL} / \mathrm{kg} / \mathrm{h}$ pela via intraóssea (tibiotarso). Foram monitoradas as frequências cardíaca e respiratória a cada 10 minutos e colhidas amostras sanguíneas venosas aos 0,30 e $60 \mathrm{~min}$ de anestesia, obtendo-se a partir destas, valores de $\mathrm{pH}$ sanguíneo, bicarbonato $\left(\mathrm{HCO}_{3}\right)$, pressão venosa de $\mathrm{CO}_{2}\left(\mathrm{PvCO}_{2}\right)$, sódio $\left(\mathrm{Na}^{+}\right)$e potássio $\left(\mathrm{K}^{+}\right)$. Os valores referentes ao equilíbrio ácido-base indicam que houve acidose respiratória em ambos os grupos, a qual foi decorrente do processo de indução sob contenção física, caracterizada por diminuição no $\mathrm{pH}$ desde o $0 \mathrm{~min}$, associado ao aumento compensatório nos valores de $\mathrm{HCO}_{3}{ }_{3}$, nos momentos 30 e $60 \mathrm{~min}$. No entanto, no que se refere aos valores obtidos de $\mathrm{Na}^{+}$e $\mathrm{K}^{+}$séricos, durante a infusão de 
ambos os fluidos, não foram observadas alterações que justifiquem a predileção por alguma destas soluções. Diante destes resultados conclui-se que a escolha entre uma das soluções avaliadas não promoveu impacto sob o equilíbrio ácido-base e hidroeletrolítico de pombos submetidos a osteossíntese de úmero.

TERMOS DE INDEXAÇÃO: Pombos, Columbia livia, osteossíntese, fluidoterapia, via intraóssea, bicarbonato, equilíbrio ácido-base.

\section{INTRODUCTION}

Fluid therapy during surgery is essential to minimize blood loss and dehydration from surgical and anesthesic procedures. Fluid therapy has great importance in bird surgery, due to its low blood volume (Gunkel \& Lafortune 2005) and high cellular metabolism (Abou-Madi \& Kollias 1992, Steinohrt 1999, Gunkel \& Lafortune 2005).

Fluid therapy may be administrated through different routes: oral, subcutaneous, intraperitoneal or intracelomatic, intravenous or intraosseous (Fowler 2007). Intravenous and intraosseous routes of administration are the most efficient and most frequently used for blood volume replacement in birds during surgery or in critical situations (Powers 2006, Fowler 2007). Intraosseous infusion is more efficient than intravenous infusion because of the easy access and the higher stability. Intraosseous infusion is specially suggested in small birds or when the peripheral venous access may be difficult due to vasoconstriction in hypovolemic birds (Valverde et al. 1993, Heatley et al. 2001, Dubé et al. 2011).
Nevertheless, fractures, fluid losses from bone marrow to extramedullar space, osteomyelitis and local pain have been described as some complications that are mainly associated to this route of administration (Dubé et al. 2011). Complications during intraosseous fluid therapy may be associated to the lack of practice of catheter insertion, time of the catheter inside the bone, or injection of hypertonic or alkaline solutions into the medullar bone space (Lennox 2008, Dubé et al. 2011). There are few data about the prevalence of osteomyelitis in birds associated of fluid therapy administration by this route. However, some studies in humans showed only a $0.6 \%$ prevalence of osteomyelitis patients submitted to intraosseous infusion (Massey 1950, Rosetti et al. 1985).

The choice of the fluid therapy depends on the clinical and biochemical conditions of the patient. Those might be especially described by serum total protein and its fractions, hematocrit and electrolytes $\left(\mathrm{Na}^{+}, \mathrm{K}^{+}\right.$and $\left.\mathrm{Cl}^{-}\right)$, associated with the degree of the dehydration and blood loss during the surgery (Montesinos \& Ardiaca 2013). Bird's blood serum usually has higher concentrations of $\mathrm{Na}^{+}$and low concentrations of $\mathrm{K}^{+}$than mammals (Gunkel \& Lafortune 2005). Administration of isotonic solutions formulated to use in mammals may affect the dynamic of body fluids, physiologic processes and heart contractility in birds. Thereby, it is important to establish which is the best fluid and the adequate volume to be administered in those patients.

This study aims to evaluate the impact of fluid therapy with lactate Ringer's solution or $0.9 \%$ saline solution, by intraosseous route, in pigeons (Columba livia) submitted to osteosynthesis of the humerus.

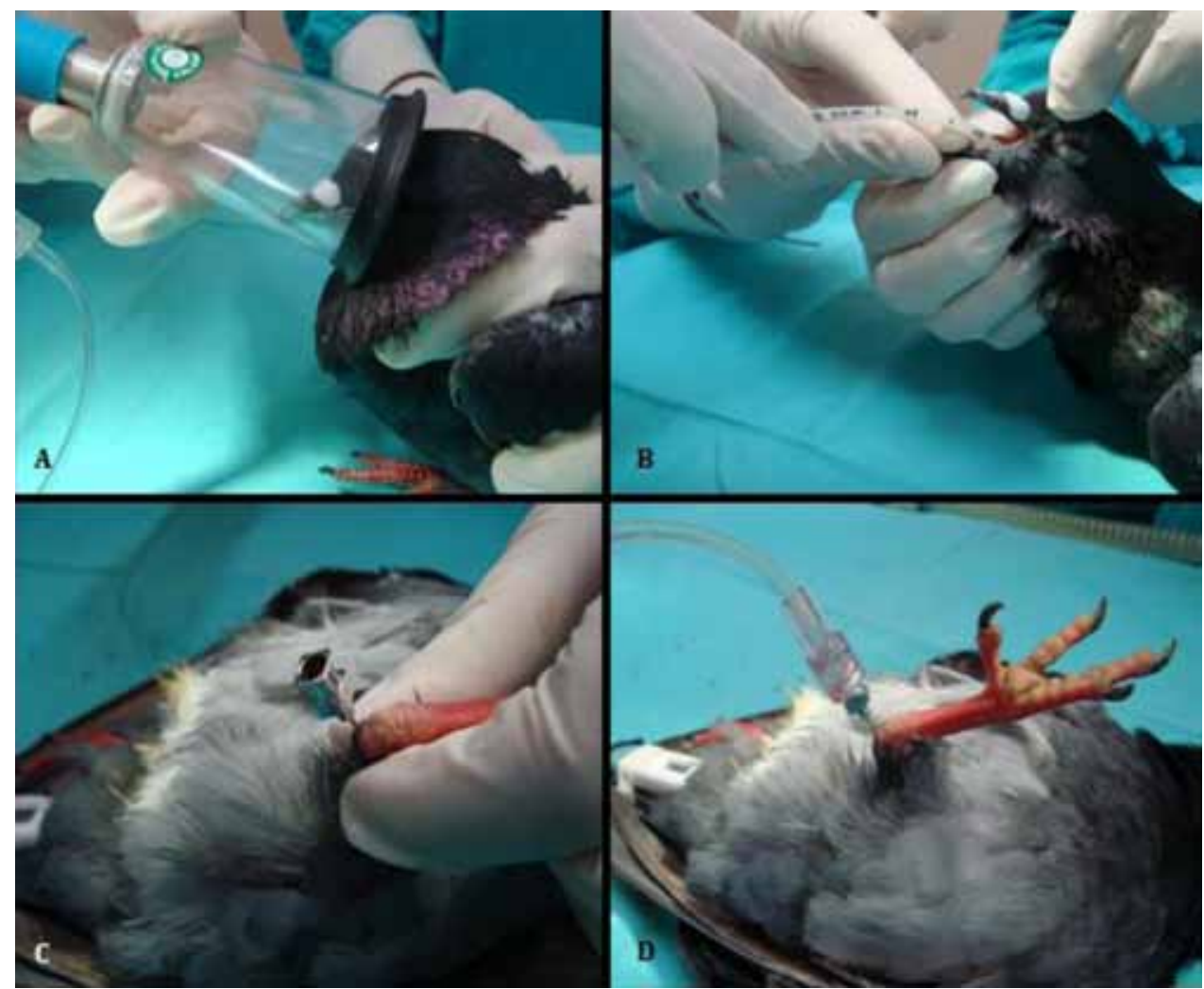

Fig.1. (A) Isoflurane anesthetic induction of pigeon by face mask. (B) Tracheal intubation with a 2.0 no cuffed tube. (C) Insertion of a $20 \mathrm{G}$ catheter into the tibiotarsus bone. (D) Fluid therapy administration. 


\section{MATERIALS AND METHODS}

This study was approved by the Institutional Animal Use and Care Committee (number 38/2008) of Federal University of Santa Maria. Eighteen adults pigeons (Columba livia), weighting $302.5 \pm 28.8 \mathrm{~g}$ were used. Those birds were submitted to osteosynthesis of humerus with bone graft (parallel study).

The birds were manually restrained and submitted to inhalant anesthesia induction, by isoflurane (Isoflurane ${ }^{\circledR}$. Cristália Prod. Farm. Ltda. Itapira. SP. Brazil) in $100 \%$ oxygen by use of a face mask (Figure 1a). After anesthetic induction, the birds were intubated with 2.0 uncuffed endotracheal tube (Figure 1b) (0 min) and maintained an expired fraction of isoflurane concentration (FE'Iso) of $3.0 \pm 0.4 \%$ with a Bain circuit $\left(\right.$ Oxigel $^{\circledR}$ São Paulo. SP. Brazil). The birds were placed on lateral recumbency on a thermal pad (Ortovet ${ }^{\circledR}$. São Paulo. SP. Brazil) to maintain body core temperature $\left(39-41^{\circ} \mathrm{C}\right)$. A $20 \mathrm{G}$ catheter was introduced into the proximal region of the tibiotarsus to fluid therapy administration (Fig.1c and 1d).

The birds were randomly assigned in two groups $(n=9)$, receiving either lactated Ringer's solution (LR) (Ringer lactato. Fresenius Kabi Brazil Ltda, Aquiraz, Ceará, Brazil) or 0.9\% sodium chloride (SC) (Cloreto de sódio 0.9\%. Fresenius Kabi Brasil Ltda. Aquiraz. Ceará. Brazil). Both solutions were administrated at a $20 \mathrm{~mL} / \mathrm{kg} / \mathrm{h}$ rate using a syringe infusion pump (Bomba de infusão B. Braun CC. modelo 8714827. Laboratórios B. Braun S.A., São Gonçalo, Rio de Janeiro, Brazil).

Surgical procedure was standardized in 40 minutes. Patient monitoring was performed during 60 minutes. Heart rate (HR) and respiratory rate (RR) were measured every 10 minutes. Venous blood samples were collected at 0,30 and 60 minutes to analyze blood $\mathrm{pH}, \mathrm{CO}_{2}$ pressure of venous blood $\left(\mathrm{PvCO}_{2}\right)$, bicarbonate concentration $\left(\mathrm{HCO}_{3}^{-}\right.$), $\mathrm{Na}^{+}$and $\mathrm{K}^{+}$concentrations (I - Stat ${ }^{\circledR} 1, \mathrm{Ab}$ bott Point of Care Inc., Illinois, USA). All animals were given $1 \mathrm{mg} /$ $\mathrm{kg}$ of meloxicam (Maxicam ${ }^{\circledR} 0.2 \%$ injectable solution. Ourofino, Ribeirão Preto. São Paulo. Brasil) and $5 \mathrm{mg} / \mathrm{kg}$ of morphine (Dimorf ${ }^{\circledR}$ Cristália Prod. Quím. Farm. Ltda, Itapira, São Paulo, Brazil), into the pectoral muscles, at the end of isoflurane anesthesia, to provide postoperative analgesia.

Statistical analysis (Graph Pad Prism 5.0 Graph Pad Prism, Graph Pad Software Inc., San Diego. California, USA) was performed by analysis of variance (ANOVA) followed by the Bonferroni's test for groups comparison along the times. Student's test was used to compare both groups, in each time. Differences were considered significant as $\mathrm{p}<0.05$.

\section{RESULTS}

No significant changes were observed in the HR or RR in both groups. During the procedure, the HR was between $168 \pm 30 \mathrm{bpm}$ to $237 \pm 37 \mathrm{bpm}$ for the LR group and $202 \pm 29 \mathrm{bpm}$ to $225 \pm 34 \mathrm{bpm}$ for the SC group. The RR ranged from $22 \pm 10 \mathrm{mpm}$ to $28 \pm 8 \mathrm{mpm}$ and from $22 \pm 8 \mathrm{mpm}$ to $31 \pm 11 \mathrm{mpm}$ for the LR and SC groups respectively.

In relation to the blood gas and electrolytes analysis, both groups showed an increase in $\mathrm{HCO}_{3}^{-}$values. This increase may be due to a rise in $\mathrm{PvCO}_{2}$, even though no statistical difference was observed when compared values with 0min (Table 1). Regarding to the impact of the fluid therapy on the electrolytes concentrations, no difference was observed on $\mathrm{Na}^{+}$or $\mathrm{K}^{+}$blood concentrations. (Table 1). No osteomyelitis was found in any pigeon during the 15day postoperative period (parallel study), based on clinical status.
Table 1. Mean and standard deviation of venous carbon dioxide pressure $\left(\mathrm{PvCO}_{2}\right), \mathrm{pH}$, bicarbonate $\left(\mathrm{HCO}_{3}-\right)$, potassium $\left(\mathrm{K}^{+}\right)$and sodium $\left(\mathrm{Na}^{+}\right)$concentrations in pigeons received lactated Ringer's solution (LR) or $0.9 \%$ sodium chloride (SC), and submitted to isoflurane anesthesia and humerus osteossyntesis

\begin{tabular}{lcccc}
\hline Variables & Group & $0 \mathrm{~min}$ & $30 \mathrm{~min}$ & $60 \mathrm{~min}$ \\
\hline $\mathrm{PvCO}_{2}$ & $\mathrm{LR}$ & $61 \pm 11.6$ & $71 \pm 17.3$ & $70 \pm 11.6$ \\
$(\mathrm{mmHg})$ & $\mathrm{SC}$ & $60 \pm 16.1$ & $67 \pm 6.9$ & $74 \pm 19.0$ \\
$\mathrm{pH}$ & $\mathrm{LR}$ & $7.266 \pm 0.054$ & $7.245 \pm 0.081$ & $7.256 \pm 0.075$ \\
& $\mathrm{SC}$ & $7.268 \pm 0.097$ & $7.240 \pm 0.059$ & $7.222 \pm 0.088$ \\
$\mathrm{HCO}_{3}{ }^{-}$ & LR & $25.7 \pm 3.0$ & $28.5 \pm 2.4^{*}$ & $29.5 \pm 2.2^{*}$ \\
$\left(\mathrm{mmol}^{+} \mathrm{L}\right)$ & $\mathrm{SC}$ & $24.6 \pm 2.0$ & $27.0 \pm 1.7^{*}$ & $28.0 \pm 2.1^{*}$ \\
$\mathrm{~K}^{+}$ & $\mathrm{LR}$ & $3.4 \pm 0.7$ & $3.4 \pm 0.6$ & $3.6 \pm 0.7$ \\
$\left(\mathrm{mmol}^{2} \mathrm{~L}\right)$ & $\mathrm{SC}$ & $3.3 \pm 0.5$ & $3.5 \pm 0.6$ & $3.8 \pm 0.7$ \\
$\mathrm{Na}^{+}$ & $\mathrm{LR}$ & $150.7 \pm 4.6$ & $151.2 \pm 4.0$ & $150.6 \pm 4.3$ \\
$(\mathrm{mmol} / \mathrm{L})$ & $\mathrm{SC}$ & $152.7 \pm 3.5$ & $152.6 \pm 3.9$ & $152.2 \pm 5.3$
\end{tabular}

* Significant difference within a group in comparison with $0 \mathrm{~min}$.

\section{DISCUSSION}

Acidemia (decrease of blood $\mathrm{pH}$ ) was observed in both groups, since $0 \mathrm{~min}$, when compared to reference values (Powell 2000). However, this pattern was not changed in both groups over time.

An increase in $\mathrm{HCO}_{3}^{-}$concentrations was observed in both groups at 30 and $60 \mathrm{~min}$. All moments showed values higher than those described for Zandvliet et al. (2001), who consider a normal $\mathrm{PvCO}_{2}$ of $37.92 \pm 4.23 \mathrm{mmHg}$ in healthy psittacines. Even though that data refer to a different species, it might suggests respiratory acidosis, once both species (psittacines and pigeons) have similar respiratory physiology, and $\mathrm{pH}$ at $0 \mathrm{~min}$, in both groups, was lower than the considered normal for pigeons (Powell 2000). Thus, blood acid-base and electrolyte analysis suggests that the birds suffered respiratory acidosis during the anesthetic procedure. The values of $\mathrm{HCO}_{3}^{-}$and $\mathrm{PvCO}_{2}$ were higher during the procedure. $\mathrm{HCO}_{3}{ }^{-}$increased significantly at $30 \mathrm{~min}$ and 60 min in both groups compared to 0 min, showing a compensatory response to respiratory acidosis. The compensatory response of acid-base imbalance in this study was very similar to that described in parrots (Amazonas sp.) affected by respiratory dysfunction (Zandvliet et al. 2001) and in crested caracaras (Caracara plancus) submitted to isoflurane and sevoflurane anesthesia (Vitaliano et al. 2006).

The results suggest that anesthetic induction by face mask along physical restraint may cause a moderate respiratory acidosis. Respiratory acidosis could be associated to the stress due to the physical restraint and some episodes of apnea occurring during anesthetic induction. Guimarães et al. (2000) and Vitaliano et al. (2006) also described similar pattern in other birds, and both studies correlate respiratory acidosis to respiratory suppression during perioperative period. It is important to point out that the RR remained quite stable during the anesthetic procedure. Furthermore, $\mathrm{PvCO}_{2}$ values remained higher since the start of the procedure.

Values of $\mathrm{pH}$ observed in this study were significantly lower than those presented by Powell (2000), who described a blood $\mathrm{pH}$ as 7.503 for awake pigeons. The comparison between the results of this study (blood pH between 
7.222 and 7.268) and those presented by Powell (2000) supports the hypothesis of respiratory acidosis caused by both physical restraint and the anesthetic procedure.

The blood gas and electrolytes analysis were obtained by a device that quantifies the $\mathrm{O}_{2}$ and $\mathrm{CO}_{2}$ concentrations, and $\mathrm{pH}$ by a direct measurement, and the $\mathrm{HCO}_{3}{ }^{-}$concentration by indirect measurement. That equipment bases on the human physiology to get those indirect values. This might promote a certain inaccuracy on the results, despite this technique is well used for dogs (Montesinos \& Ardiaca 2013). Studies in other species had been conducted in order to improve the technique (Kilgallon et al. 2008, McCain et al. 2010, Vannucchi et al. 2012, Lewbart et al. 2014). However, as discussed earlier, the parameters observed here, and combined with a compensatory response of both groups suggest a less significant effect of these variants to the shown data.

The results of $\mathrm{Na}^{+}$and $\mathrm{K}^{+}$concentrations, along with other parameters, such as $\mathrm{PvCO}_{2}, \mathrm{pH}, \mathrm{HCO}_{3}^{-}$and perioperative monitoring, showed a similar pattern between LR and SC, that cannot justify any preference for the use of each one fluid therapy solution. Despite limited data on the effect of different fluid therapy solution on birds, West et al. (2013) described a similar study performed in dogs. They compared the infusion of $0.9 \%$ saline solution, Hartmann's solution (which composition is similar to lactated Ringer's solution) or a polyconic glucose-free maintenance solution (Normofundin OP, B. Braun Medical Ltd, UK) for 2 hours, at a $10 \mathrm{~mL} / \mathrm{kg} / \mathrm{h}$ rate, and they concluded the very few differences among perioperative administration of the solutions, and the differences observed cannot be attributed to $\mathrm{SC}$ as responsible promoter of a potential metabolic acidosis. On the other hand, Scheingraber et al. (1999) compared $0.9 \%$ sodium chloride e lactated Ringer's solution infusions in human, and observed significative changes in blood $\mathrm{pH}$, as SC group showed a decrease in $\mathrm{pH}$ from 7.4 to near 7.2 after 120 minutes at a $30 \mathrm{ml} / \mathrm{kg} / \mathrm{h}$ infusion rate. The authors attributed this decrease in $\mathrm{pH}$ to an increase in serum chloride as a hyperchloremic metabolic acidosis.

Despite the importance and applicability in providing fluid therapy in birds, data about fluid therapy in different species of bird is relatively poor. Polytraumatized bird care consists in a relevant part of the total treatments done in wild life care centers, where crystalloid solutions are the main choice to expand/maintain patients' volemia. The results shown here support that the fluid solution do not influence the bird's acid-base or electrolyte balances when used at a $20 \mathrm{~mL} / \mathrm{kg} / \mathrm{h}$ infusion rate for 60 minutes. Hence, this study provided considerable data in fluid therapy in birds.

\section{CONCLUSION}

According to the results of the present study, $0.9 \%$ saline solution or lactated Ringer's solution at a $20 \mathrm{~mL} / \mathrm{kg} / \mathrm{h}$ rate infusion, by intraosseous route, do not cause significant changes on acid-base balance and electrolyte concentrations in pigeons.

\section{REFERENCES}

Abou-Madi A. \& Kollias GV. 1992. Avian fluid therapy, p.1154-1159. In: Kirk R.W. \& Bonagura J.D. (Eds), Current Veterinary Therapy. W.B. Saunders, Philadelphia.

Dubé C., Dubois I. \& Struthers J. 2011. Intravenous and intraosseous fluid therapy in critically ill birds of prey. J. Exot. Pet Med. 20(1):21-26.

Fowler A. 2007. Fluid therapy in wildlife. Proc. National Wildlife Rehabilitation Conference. National Wildlife Rehabilitators Association, Freemantle.

Guimarães L.D., Moraes A.N., Campello R.A.V., Oleskovicz N. \& Ulliana D. 2000. Estudo comparativo entre sevofluorano. halotano e isofluorano em Gallus domesticus. Ciência Rural 30:999-1004.

Gunkel C. \& Lafortune M. 2005. Curent techniques in avian anesthesia. Sem. Avian Exot. Pet Med. 14:263-276.

Heatley J.J., Marks S. \& Mitchell M. 2001. Raptor emergency and critical care (therapy and techniques). Compendium 23:561-570.

Kilgallon C., Bailey T., Arca-Ruibal B., Misheff M. \& O'Donovan D. 2008. Blood-gas and acid-base parameters in nontranquilized Arabian Oryx (Oryx leucoryx) in the United Arab Emirates. J. Zoo Wildl. Med. 39(1):6-12.

Lennox A.M. 2008. Intraosseous catheterization of exotic animals. J. Exot. Pet Med. 17:300-306.

Lewbart G.A., Hirschfeld M., Denkinger J., Vasco K., Guevara N., García J., Muñoz J. \& Lohmann K.J. 2014. Blood gases, biochemistry, and hematology of Galapagos Green Turtles (Chelonia Mydas). Plos One 9(5):1-7.

McCain S.L., Flatland B., Schumacher J.P., Clarke Lii E.O. \& Fry M.M. 2010. Comparison of chemistry analytes between 2 portable, commercially available analyzers and a conventional laboratory analyzer in reptile. Vet Clin. Pathol. 39(4):474-479.

Massey L.W.C. 1950. Bone-marrow infusions: intratibial and intravenous routes compared. Brit. Med. J. 2:197-198.

Montesinos A. \& Ardiaca M. 2013. Acid-base status in the avian patient using a portable point-of-care analyzer. Vet. Clin. Exot. Anim. 16:47-69.

Powell F.L. 2000. Respiration, p.233-264. In: G.C. Whittow (Ed.), Sturkie's Avian Physiology. $5^{\text {th }}$ ed. Academic Press Elsevier, Melbourne.

Powers L.V. 2006. Techniques for drug delivery in Psittacine birds. J. Exot. Pet Med. 15:193-200.

Rosetti V.A., Thompson B.M., Miller J., Mateer J.R. \& Aprahamian C. 1985. Intraosseous infusion: an alternative route of pediatric intravenous access. Annals Emerg. Med. 14:885-888.

Scheingraber S., Rehm M., Sehmisch C. \& Finsterer U. 1999. Rapid saline infusion produces hyperchloremic acidosis in patients undergoing gynecologic surgery. Anesthesiology 90(5):1265-1270.

Steinohrt L.A. 1999. Avian fluid therapy. J. Avian Med. Surg. 13:83-91.

Valverde A., Bienzle D., Smith D.A., Dyson D.H. \& Valliant A.E. 1993. Intraosseous cannulation and drug administration for induction of anesthesia in chickens. Vet. Surg. 22:240-244.

Vannucchi C.I., Rodrigues J.A., Silva L.C.G., Lucio C.F. \& Veiga G.A.L. 2012. A clinical and hemogasometric survey of neonatal lambs. Small Rumin. Res. 108(1/3):107-112.

Vitaliano S.N., Thiesen R., Escobar A., Belmonte E.A., Valadão C.A.A., Nunes N. \& Werther K. 2006. Estudo das variáveis hemogasométricas e cardiorrespiratórias em carcarás (Polyborus plancus) subsequentemente anestesiados com isofluorano e sevofluorano. Anais X Congresso e XV Encontro da Associação Brasileira de Veterinários de Animais Selvagens, São Pedro. SP, Brasil, p.22-25.

West E., Pettitt R., Jones R.S., Cripps P.J. \& Mosing M. 2013. Acid-base and electrolyte balance following administration of three crystalloid solutions in dogs undergoing elective orthopedic surgery. Vet. Anaesth. Analg. 40:482-493.

Zandvliet M.M.J.M., Dorrestein G.M. \& Van der Hage M. 2001. Chronic pulmonary interstitial fibrosis in Amazon parrots. Avian Pathol. 30:517524 . 